\title{
Evaluation of Early Group of Sugarcane Genotypes for Yield and Quality Traits
}

\author{
Nirmodh Prabha* \\ Department of Genetics and Plant Breeding, Sant Kabir College of Agriculture and Research \\ Station, IGKV, Kawardha, (C.G.), India \\ *Corresponding author
}

\section{A B S T R A C T}

\section{Keywords}

Sugarcane, Yield traits, Biochemical analysis

\section{Article Info}

\section{Accepted:}

07 January 2021

Available Online:

10 February 2021
The present investigation entitled "Evaluation of sugarcane genotypes for yield \& quality traits" was carried out under AICRP on Sugarcane, at Sant Kabir College of Agriculture \& Research station, Indira Gandhi Krishi Vishwavidyalaya, Kawardha, Kabirdham (C.G.) during 2016-17. The twelve genotypes and four standard (Co 85004, Co 94008, CoC 671 and CoM 265) of early group of sugarcane were evaluated in the completely Randomized block design with three replications for their yield performance and other yield \& quality attributing traits. The genotypes of sugarcane were collected from Central Sugarcane Research Station (MPKV), Padegaon (Maharashtra). The observation taken on stem height, single cane weight, length of nodes, yield and other biochemical analysis viz., Brix $\%$, purity $\%$ and sucrose $\%$. The maximum cane yield was observed in entry MS 13081 (116.47 t/ha), highest stem height in standard check COC $671(345.53 \mathrm{~cm})$, maximum weight of single cane in standard check COM $265(2.348 \mathrm{~kg})$ and highest nodal length in entry CO $13004(13.98 \mathrm{~cm})$. In biochemical analysis maximum cane Brix\% was observed in the entry CO 13002 (21.04\%), maximum Purity\% in the CoSnK 13102 (80.98 $\%)$, maximum Juice Extraction \% in the entry Co-13003 (62.93\%) \& maximum sucrose\% in juice was observed in the entry Co 13003 (12.05).

\section{Introduction}

Sugarcane (Saccharum officinarum L.) is the main sources of sugar in India and holds a prominent position as a cash crop. Sugarcane is a monocotyledonous crop that is cultivated in the tropical and subtropical regions of the world, primarily for its ability to store high concentrations of sucrose, or sugar, in the stem. India is the world's largest consumer and the second biggest sugar producer. There is consistently increase in sugarcane area, production and productivity after independence. Sugarcane is the main source of sugar (80\%) globally and holds a prominent position as a cash crop. It is one of the main crops of earning foreign exchange. Genetic improvement of varieties plays a vital role in the development of sugar industries in almost all sugarcane growing countries. Improved cane yields, sucrose content and disease and pest resistance and maintaining acceptable fibre levels for milling are usually the main breeding objectives in most 
sugarcane breeding programmes (Jackson, 2005). Sugarcane varieties in commercial cultivation are complex polyploid. The heterozygous and polyploid nature of this crop has resulted in development of greater genetic variability. The information on the nature and the magnitude of variability present in the breeding material is of prime importance for a breeder to initiate any effective selection program. The effectiveness of selection for sugar yield and its components depends largely on the genetic variability present in the breeding population of sugarcane and the heritability of the traits. It is necessary to identify traits with high genetic variation. The easiest way to estimate variance components is to test a large number of genotypes for two or more years and at two or more locations (Mayo, 1980).

\section{Materials and Methods}

The study was conducted at the Research Farm of Sant Kabir College of Agriculture \& Research station, Indira Gandhi Krishi Vishwavidyalaya, Kawardha, Kabirdham (C.G.) during 2016-17. Eight sugarcane genotypes viz. CO 13002, CO 13003, CO 13004, CON 13071, CON 13072, CoSnK 13101, CoSnK 13102, MS 13081 and four standard varieties Co-85004, Co-94008 and CoC-671 and CoM 265 of early group of sugarcane were evaluated in the completely Randomized block design (RCBD) with three replications. The genotypes of sugarcane were collected from Central Sugarcane Research Station (MPKV), Padegaon (Maharashtra). Each entry had 5 meters long 4 rows at 1.2 meters row to row distance. Two-three budded sets with overlapping arrangement were planted in single row system. The sets were placed overlapping in the centre of furrows, after covering the sets with soil, fertilizer dose@300 kg nitrogen, 100 kg phosphorus and $100 \mathrm{~kg}$ potassium per hectare was applied as, one third nitrogen with full dose of phosphorus and potassium at the time of sowing; the remaining nitrogen was applied in two splits. All the cultural practices were uniformly applied. The irrigation was applied at 9-10 days interval in summer and 15-16 days interval in winter. The harvesting of sugarcane crop was done at maturity of the crop.

The observations taken in field on plant height, single cane weight, length of nodes, diameter of cane and yield quintal per hectare and other biochemical analysis was done in the laboratory of the Bhoramdeo Sahakari Shakkar Utpadak Karkhana Maryadit, Kawardha, Chhattisgarh on Brix percentage, juice percentage, purity percentage and sucrose percentage. The data on cane yield and yield parameters were analyzed statistically using analysis of variance and LSD test was applied to discriminate the superiority of the means of different varieties as suggested by Gomez and Gomez (1984).

\section{Results and Discussion}

The results of the study revealed that there were highly significant differences in the mean values for cane yield and yield components. The results of the study presented in Table- 1 revealed that the average stem height maximum was observed in the entry CO $13004(340.53 \mathrm{~cm})$ followed by entry CO $13003(301.93 \mathrm{~cm})$ and CO 13002 $(289.93 \mathrm{~cm})$ and minimum was recorded in the entry CoN-13072 $(270.60 \mathrm{~cm})$. None of the entry was found significantly superior over the best standard CoC-671 $(345.53 \mathrm{~cm})$. In case of node length, the maximum average node length was observed in the entry CO $13004(13.98 \mathrm{~cm})$ followed by entry CoSnK $13102(13.64 \mathrm{~cm})$ and CoSnK 1310113.30 $\mathrm{cm})$ and minimum was recorded in the entry MS $13081(11.17 \mathrm{~cm})$. None of the entry was found significantly superior over the best standard CoC-671 $(13.65 \mathrm{~cm})$. The results 
regarding single cane weight $(\mathrm{kg})$ revealed that the sugarcane entry CoSnK 13102 remained on top ( $2.126 \mathrm{Kg}$ per cane) followed by standard MS $13081(2.002 \mathrm{Kg})$ and $\mathrm{Co}$ $13003(1.875 \mathrm{Kg})$ and minimum average weight was recorded in the standard Co$13002(1.610 \mathrm{Kg})$. None of the entry was found significantly superior over the best standard COM $265(2.348 \mathrm{Kg})$. As regards the average cane diameter $(\mathrm{cm})$, maximum was observed in the entry MS $13081(3.36 \mathrm{~cm})$ followed by standard CoSnK $13102(3.33 \mathrm{~cm})$ and CON $13072(3.09 \mathrm{~cm})$ and minimum was recorded in the entry Co-13004 $(2.79 \mathrm{~cm})$. None of the entry was found significantly superior over the best standard COM 265 $(3.26 \mathrm{~cm})$.

The data regarding average cane yield presented in Table-1 revealed that entry MS 13081 remained on top (116.47 t/ha cane yield) followed by entry CON 13071 and standard COM 265, with average cane yield of 110.73 and $103.39 \mathrm{t} / \mathrm{ha}$, respectively and minimum was recorded in the entry CoSnK 13101 (67.69 t/ha). Moreover, rest of the sugarcane entries displayed average cane yield, but could not out yielded the best standard COM 265 (103.39 t/ha) variety. None of the entry was found significantly superior over the best standard.

This suggested that all sugarcane genotypes were genetically variable and a considerable amount of variability existed among them, therefore, these sugarcane genotypes would respond positively to selection. It is accepted that sugarcane varieties are greatly affected by genetic makeup (El-Geddaway, et al., 2002). The variation in cane yield and yield components among the varieties may be attributed due to their dissimilarity in genetic make up (Varghese et al., 1985 and Mali and Singh, 1995). Memon et al., (2005) and Panhwar, et al., (2008) reported great variability among the sugarcane genotypes for cane yield and yield components.

Table.1 Average data of IVT-Early group of Sugarcane genotypes

\begin{tabular}{|l|c|c|c|c|c|}
\hline \multicolumn{1}{|c|}{ Entries } & $\begin{array}{c}\text { Plant } \\
\text { height }(\mathbf{c m} \text { ) }\end{array}$ & $\begin{array}{c}\text { Nodal } \\
\text { length }(\mathbf{c m})\end{array}$ & $\begin{array}{c}\text { Weight of } \\
\text { single cane } \\
(\mathbf{k g})\end{array}$ & $\begin{array}{c}\text { Diameter } \\
(\mathbf{c m})\end{array}$ & $\begin{array}{c}\text { Cane yield } \\
\text { (t/ha) }\end{array}$ \\
\hline CO 13002 & 289.93 & 12.27 & 1.610 & 2.80 & 102.23 \\
\hline CO 13003 & 301.93 & 12.57 & 1.875 & 2.97 & 93.76 \\
\hline CO 13004 & 340.53 & 13.98 & 1.844 & 2.79 & 93.81 \\
\hline CON 13071 & 287.40 & 12.63 & 1.714 & 2.90 & 110.73 \\
\hline CON 13072 & 270.60 & 13.05 & 1.785 & 3.09 & 84.86 \\
\hline CoSnK 13101 & 288.53 & 13.30 & 1.690 & 2.97 & 67.69 \\
\hline CoSnK 13102 & 283.73 & 13.64 & 2.126 & 3.33 & 88.58 \\
\hline MS 13081 & 285.33 & 11.17 & 2.002 & 3.36 & 116.47 \\
\hline Standards & & & & & \\
\hline CO 85004 & 261.27 & 9.69 & 1.489 & 2.64 & 78.21 \\
\hline CO 94008 & 316.00 & 12.74 & 1.933 & 3.02 & 85.9 \\
\hline COC 671 & 345.53 & 13.65 & 2.056 & 3.09 & 102.44 \\
\hline COM 265 & 316.40 & 12.71 & 2.348 & 3.26 & 103.39 \\
\hline Over All Mean & $\mathbf{2 9 8 . 9 3}$ & $\mathbf{1 2 . 6 2}$ & $\mathbf{1 . 8 7}$ & $\mathbf{3 . 0 2}$ & $\mathbf{9 4 . 0 1}$ \\
\hline CD (5\%) & $\mathbf{2 8 . 4 7}$ & $\mathbf{1 . 0 2}$ & $\mathbf{0 . 3 1}$ & $\mathbf{0 . 1 7}$ & $\mathbf{1 5 . 5 8}$ \\
\hline CV\% & $\mathbf{5 . 7 7}$ & $\mathbf{4 . 8 9}$ & $\mathbf{9 . 9 4}$ & $\mathbf{3 . 4 8}$ & $\mathbf{1 0 . 0 6}$ \\
\hline
\end{tabular}


Table.2 Bio-chemical data of IVT-Early group of Sugarcane genotypes

\begin{tabular}{|l|c|c|c|c|}
\hline \multicolumn{1}{|c|}{ Entries } & Juice Extraction \% & Brix\% & Sucrose \% in Juice & Purity\% \\
\hline CO 13002 & 61.35 & 21.04 & 11.80 & 80.57 \\
\hline CO 13003 & 62.93 & 21.02 & 12.05 & 80.79 \\
\hline CO 13004 & 56.10 & 18.88 & 10.01 & 79.33 \\
\hline CON 13071 & 56.52 & 19.73 & 10.38 & 79.49 \\
\hline CON 13072 & 58.36 & 18.47 & 10.11 & 79.33 \\
\hline CoSnK 13101 & 59.07 & 20.78 & 11.15 & 79.72 \\
\hline CoSnK 13102 & 55.11 & 20.63 & 10.67 & 80.98 \\
\hline MS 13081 & 57.46 & 20.43 & 10.96 & 80.25 \\
\hline Standards & & & & \\
\hline CO 85004 & 56.53 & 20.43 & 10.82 & 80.21 \\
\hline CO 94008 & 58.70 & 19.33 & 10.50 & 79.47 \\
\hline COC 671 & 57.39 & 20.72 & 11.19 & 80.24 \\
\hline COM 265 & 57.64 & 18.61 & 10.22 & 79.45 \\
\hline
\end{tabular}

The results of biochemical analysis presented in Table-2 revealed that the maximum cane Brix \% was observed in the entry CO 13002 (21.04\%) followed by Co 13003 (21.02\%) and CoSnK 13101 (20.78\%) and minimum was recorded in the entry CON 13072 $(18.47 \%)$. In case of purity percent, the maximum Purity\% was observed in the CoSnK $13102(80.98 \%)$ followed by Co $13003(80.79 \%)$ and co $13002(80.57 \%)$ and minimum was recorded in the entry Co 13004 (79.33\%) \& CON $13072(79.33 \%)$.

The results regarding Juice Extraction percent, the maximum Juice Extraction \% was observed in the entry Co-13003 (62.93\%) followed by Co 13002 (61.35\%) and CoSnK $13101(59.07 \%)$ and minimum was recorded in the entry CoSnK 13102 (55.11\%). As regards the sucrose percent in Juice, maximum was observed in the Co 13003 (12.05) followed by Co 13002 (11.80) and standard $\mathrm{CoC} 671$ (11.19) and minimum was recorded in the entry Co 13004 (10.01). Similar results were also reported by Tena $e t$ al., (2016), Shikanda et al., (2017), Shitahun et al., (2018) and Singh et al., (2019).
On the basis of overall performance, it was concluded that entries viz Co 13004, CoSnk 13102, MS 13081, CON 13071, Co 13002, Co 13003 showed better performance in respect to cane yield, yield contributing traits and biochemical traits may be evaluated at different agro-climatic zones to know the stability and its real performance over the locations. Hence, it was suggested that the selected sugarcane genotypes should be further tested under potential area for identification as best cultivars for general cultivation.

\section{References}

AICRP (S) Technical Bulletin - No. 1 S. K. Shukla Lalan Sharma S. K. Awasthi A. D. Pathak ICAR-All India Coordinated Research Project on Sugarcane (ICARIndian Institute of Sugarcane Research) Lucknow 226002

El-Geddaway, I. H., D. G. Darwesh., A. A. El-Sherbiny., E. Eldin and A. El-Hadi (2002). Effect of row spacing and number of buds/seed sets on growth characters of ratoon crops for some sugarcane varieties. Pakistan Sugar. J. 
17:7-14.

Gomez, K. A. and A. A. Gomez (1984). Statistics for Agricultural Research (3rd ed.) John Willey and Sons, New York. pp. 142.

Jackson PA (2005). Breeding for improved sugar content in sugarcane. Field Crops Research 92:277-290.

Junejo, S., M. Chohan, A. A. Junejo, G. M. Kaloi, R. N. Panhwar and M. Y. Arain (2009). Comparative Performance of Elite Sugarcane Genotypes in 4th Cycle for Cane yield, Yield components, Quality and Borer Complex Infestation, The J. Anim. Plant Sci. 19(4): 197-201.

Mali, A. L. and P. P. Singh (1995). Quality of sugarcane influenced by varieties in relation to varying row spacing. Indian Sugar 45:451-456.

Mayo O (1980). The Theory of Plant Breeding. Clarendon Pres-Oxford. New York.

Memon, Y. M., D. B. Panhwar., R. N. Panhwar., A. F. Soomro., M. Chohan., A. H. Mari and G. M. Kaloi (2005). Evaluation and selection of elite sugarcane clones in 4th cycle for some quantitative and qualitative attributes under Thatta conditions. Pakistan Sugar. J. 20:8-12.

Panhwar, R. N., M. Chohan., D. B. Panhwar., M. A. Memon., Y. M. Memon and M. A. Panhwar (2008). Relative yield and quality appraisal of divergent sugarcane clones in 4th cycle under Thatta climatic conditions. Pakistan Sugar. J. 23:11-15.
S. Junejo, G. M. Kaloi, R. N. Panhwar, M. Chohan, A. A. Junejo and A. F. Soomro. (2010). Performance Of Some Newly Developed Sugarcane Genotypes For Some Quantitative And Qualitative Traits Under Thatta Conditions, The Journal of Animal \& Plant Sciences 20(1): 40-43.

Shikanda E, Jamoza J, Kiplagat O (2017). Genotypic evaluation of sugarcane (Saccharum spp. hybrids) clones for sucrose content in western Kenya. Journal of Plant Breeding and Crop Science 9(3):30-36.

Shitahun A., Feyissa T. and Abera D. (2018). Performances Evaluation of Advanced Sugarcane Genotypes (CIRAD 2013) at Metahara Sugar Estate, Ethiopia. Int. J. Adv. Res. Biol. Sci. 5(1): 91-104.

Singh G, Mishra KM, Sangera GS (2019). Variability and character association for commercial cane sugar and its components in early maturing sugarcane clones. Agricultural Research Journal 56(2):321-3214.

Tena E, Mekbib F, Ayana A (2016). Heritability and correlation among sugarcane (Saccharum spp.) yield and some agronomic and sugar quality traits in Ethiopia. American Journal of Plant Sciences 7:1453-1477.

Varghese, S. S., N. N. Potty and S. S. Nazir (1985). Performance of different sugarcane genotypes in agro-climatic conditions of Kerala. Indian Sugar $35: 85-88$.

\section{How to cite this article:}

Nirmodh Prabha. 2021. Evaluation of Early Group of Sugarcane Genotypes for Yield and Quality Traits. Int.J.Curr.Microbiol.App.Sci. 10(02): 648-652. doi: https://doi.org/10.20546/ijcmas.2021.1002.078 